nervousness, or anaemia he runs a risk of being diagnosed as "lead poisoning." So it must always be remembered in such cases that epidemiologically acceptable evidence of a causal association between the symptoms and the level of lead absorption is not available.-I am, etc.,

\section{K. Williams}

Leatherhead,

Surrey

1 Lane, ${ }_{1968,}^{\text {R. }}$, E. et al., British Medical fournal,

\section{Yellow Fever Vaccination}

SIR,-Much inconvenience and irritation is caused at this yellow fever vaccination centre to patients who have to be refused vaccination because they have been vaccinated against smallpox by their practitioners a few days before.

Burroughs Wellcome, who make the yellow fever vaccine, state: "Smallpox and yellow fever may be given simultaneously in an emergency but if smallpox vaccination is carried out first, and it 'takes,' 21 days must elapse before yellow fever vaccine may be given."

The Department of Health and Social Service gives similar advice in its "Notice to Travellers," except that it specifies "primary" vaccination rather than vaccination which has taken. All authorities agree that yellow fever vaccine should be given first, and it would greatly help if practitioners would advise their patients needing yellow fever vaccination to have it first and refrain from vaccinating them against smallpox until this has been done.-I am, etc.,

Medical Department,

H. J. FrIEND

Unilever House,

\section{Rhesus Isoimmunization and Twins}

SIR,-We read with interest the paper by Dr. I. M. Ellis and others (7 March 1970, p. 609) on rhesus isoimmunization in association with multiple pregnancy, and would like to report our recent experience of such a case. Intrauterine transfusion of twins has been recorded by three other groups. ${ }^{1-3}$ Some of the difficulties in identifying each sac, using radio-opaque media or various dyes, together with the difficulties in interpreting liquor analysis and attempting intrauterine transfusion have been described by these authors. To make accurate prediction for each child it is necessary to sample each sac separately.

Our patient was pregnant for the fourth time. She was aged 30 , with blood group $\mathbf{O}$ rhesus negative, probable genotype cde/cde. The father was group A rhesus positive, probable genotype CDe/CDe.

In 1964 and 1966 she had had spontaneous vertex deliveries at home and there is no record of the presence of antibodies. In 1970 she had a spontaneous vertex delivery at term of a live infant. The infant was jaundiced at birth, but did not require exchange transfusion. Antibodies were recorded at 28 weeks' gestation-anti-D $1 / 2$ enzyme, 1/2 I.A.G.T., and anti-C 1/4 enzyme. At term the readings were anti-D 1/32, 1/2 I.A.G.T., anti-C 1/8 enzyme.
In the present pregnancy a diagnosis of twins was made at her first visit in the 29th week and antibodies were found. The patient was admitted to hospital and serial amniocentesis performed (Table I). Routine check on antibody titre was kept and total oestriol (Table II).

TABLE II-Serial Oestriol Estimations on 24-hour Collection of Urine

\begin{tabular}{r|c|c}
\hline Date & $\begin{array}{c}\text { Gestational Age } \\
\text { in Weeks }\end{array}$ & $\begin{array}{c}\text { Total Oestrogens } \\
\text { in } \mathbf{m g} / 24 \text { hours }\end{array}$ \\
\hline 29 November & $33+$ & 14 \\
2 December & $34+$ & 11 \\
6 December & $34+$ & 11 \\
9 December & 35 & 12 \\
13 December & $35+$ & 18 \\
\hline
\end{tabular}

An elective lower uterine segment caesarean section was performed at the end of the 36th gestational week. Two premature, uniovular, male children, weighing $1.65 \mathrm{~kg}$ levels on the urine estimated regularly

and $1.6 \mathrm{~kg}$ were delivered. Immediate replacement transfusions were carried out, and a further four replacement transfusions for twin I and a further three replacement transfusions for twin II were required (Table III).

The position of the placentae, anterior and to the left (located by sonar) and the position of the sacs, one lying almost directly anteriorly to the other (located at caesarean section) precluded accurate prediction for each child and precluded also intrauterine transfusion, though it was indicated.-We are, etc.

ANDREW AULd Evelyn M. MCNicol

Robroyston Hospital,
Glasgow

1 Bowes, W. A., and Droegemueller, W., California Medicine, 1968, 108, 380.
Crosby, W. M., and Gheen, D. L., Obstetrics and Gynecology, 1967, 29, 674. L., Obstetrics Raphael, M. J., Gordon, H., and Schiff, D.

TABLE I-Amniocentesis

\begin{tabular}{|c|c|c|c|c|c|c|}
\hline \multirow{2}{*}{ Date } & \multirow{2}{*}{$\begin{array}{c}\text { Gestational Age } \\
\text { in Weeks }\end{array}$} & \multirow{2}{*}{$\begin{array}{l}\text { Optical Density } \\
\text { Difference at } \\
450 \mathrm{~m} \mu\end{array}$} & \multicolumn{3}{|c|}{ Bilirubin Content in $\mathrm{mg} / 100 \mathrm{~m}$} & \multirow{2}{*}{$\begin{array}{l}\text { Position on Liley's } \\
\text { Prediction Graph }\end{array}$} \\
\hline & & & Total & Direct & Indirect & \\
\hline \multirow[t]{2}{*}{$\begin{array}{l}18 \text { November } \\
25 \text { November } \\
1 \text { December } \\
16 \text { December }\end{array}$} & \multirow[t]{2}{*}{\begin{tabular}{|c|}
32 \\
33 \\
34 \\
36 \\
(at caesarean \\
section)
\end{tabular}} & $\begin{array}{rr}0.100 \\
0.090 \\
0.085 \\
\text { Sac } 10.185\end{array}$ & $\begin{array}{l}0.210 \\
0.200 \\
0.143 \\
0.386\end{array}$ & $\begin{array}{l}0.100 \\
0.050 \\
0.061 \\
0.230\end{array}$ & $\begin{array}{l}0.110 \\
0.150 \\
0.082 \\
0.156\end{array}$ & $\begin{array}{l}\text { Upper Zone } 2 \\
\text { Upper Zone } 2 \\
\text { Upper Zone } 2 \\
\text { Lower Zone } 3\end{array}$ \\
\hline & & Sac $20 \cdot 150$ & $0 \cdot 296$ & $0 \cdot 190$ & 0.106 & Lower Zone 3 \\
\hline
\end{tabular}

TABLB III

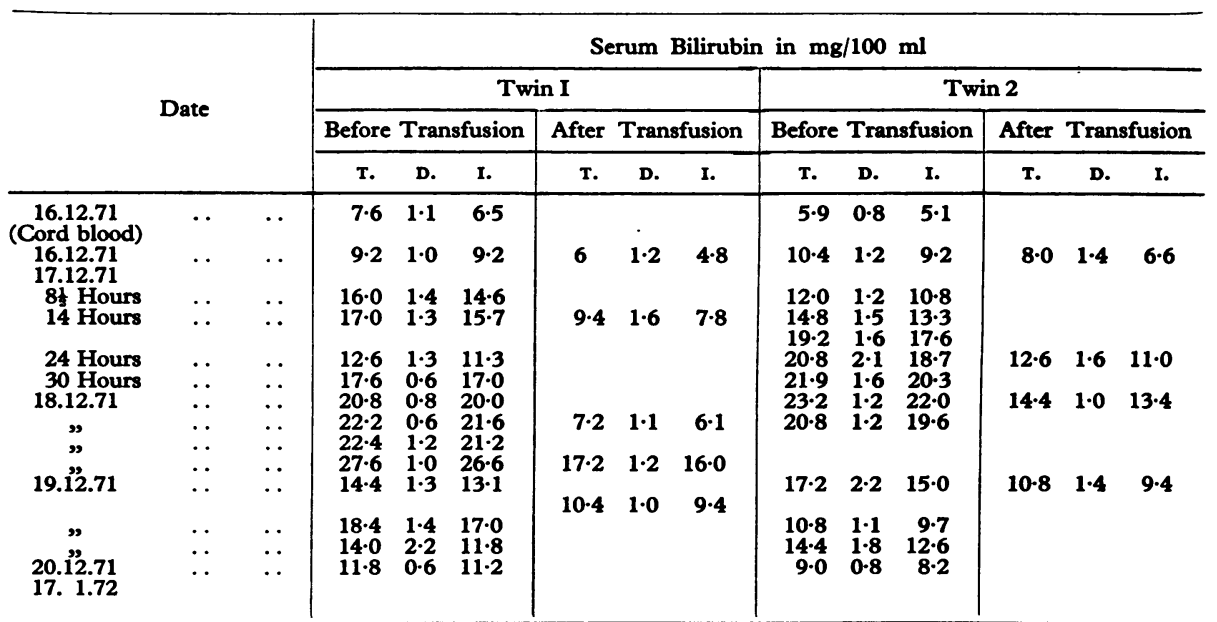

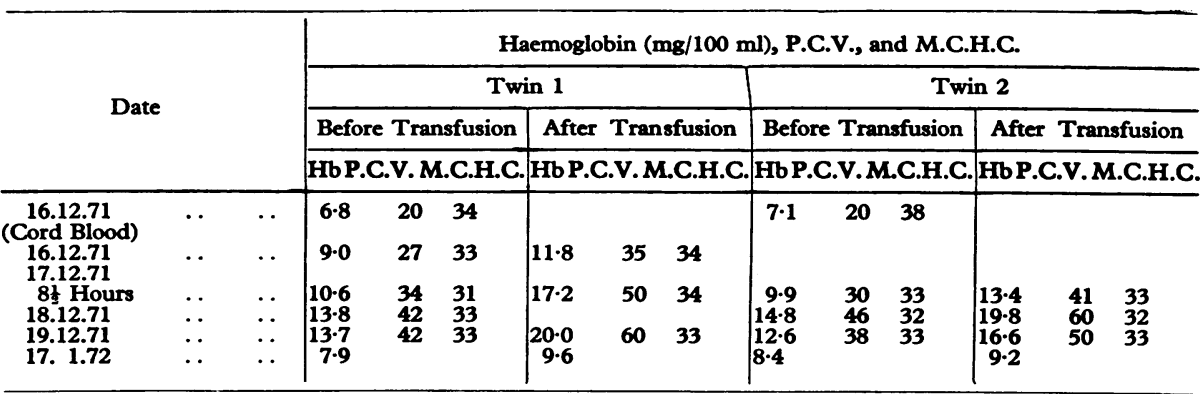

\section{$\mathbf{T}=$ Total}

$\mathbf{I}=$ Indirect

$\mathbf{H b}=$ Haemoglobin

M.C.H.C. = Mean corpuscular haemoglobin concentration

\section{Treatment of Early Breast Cancer}

SIR,-We must apologize for requesting the others (20 May, p. 423) and the accompanycourtesy of your columns once more to ing leading article (p. 417). But it appears discuss the paper on the treatment of early from the letter by Sir Hedley (24 June, p. breast cancer by Sir Hedley Atkins and 765) that the criticisms in our letter (17 